\title{
Entrevista como Experiência, Loucura como Método: Composição de uma
}

\author{
Ética do Encontro
}

\author{
Richard de Oliveira* \\ Universidade de São Paulo - USP, São Paulo, SP, Brasil \\ ORCID: https://orcid.org/0000-0002-4638-8421 \\ Adriana Marcondes Machado** \\ Universidade de São Paulo - USP, São Paulo, SP, Brasil \\ ORCID: https://orcid.org/0000-0002-5513-8723
}

\section{RESUMO}

Neste artigo apresentamos e desdobramos um procedimento de entrevista que busca romper com uma posição de exterioridade em entrevistas de pesquisas em psicologia. Com o objetivo de agir em discursos que oferecem à loucura o trato de um evento individual e psicológico, e tomando a vida e a obra de Robert Schumann como ampliadora do campo de reflexão sobre a relação entre música e loucura, realizamos entrevistas com seis intérpretes da obra do compositor, de modo a compreender o atravessamento da vivência/experiência desses músicos com a produção do autor e com o tema da loucura. Neste procedimento de entrevista, que nomeamos encontro-entrevista, a dimensão de experiência é acolhida, realçada e explorada, fazendo operar no encontro a tragicidade intrínseca à relação música-loucura. Para sustentar a potência transgressiva de tal relação, criamos um percurso narrativo especificamente para este artigo, estratégia que utilizamos para evitar que o objeto da pesquisa fosse capturado em um campo de determinações inequívocas e representacionais. Por fim, apontamos que os encontros-entrevistas, ao comporem acordos polifônicos entre elementos heterogêneos, evidenciam que, no procedimento da entrevista, a forma de conhecer é indissociável à experiência em que o dito se constitui.

Palavras-chave: entrevista, experiência, loucura, Robert Schumann.

\section{Interview as an Experience, Madness as Method: Composition of an Ethics}

\section{of the Encounter}

\begin{abstract}
In this paper, we present and unfold an interview procedure that breaks with a position of exteriority in Psychology research interviews. Aiming to act on discourses that address madness as an individual and psychological fact and taking Robert Schumann's life and work as a broader field of reflection on the relationship between music and madness, we conducted interviews with six of his interpreters, in order to understand the crossing between these
\end{abstract}


musicians' experiences, the author's work and the madness subject. In these interviews' procedures, which we named encounter-interviews, the extent of the experience is sheltered, highlighted and explored, making the intrinsic tragicness of the music-madness relationship operate in the encounter. In order to sustain the transgressive power of such a relationship, we created a narrative path specifically for this article, a strategy we use to prevent the research object from being captured in a field of unambiguous and representational determinations. Finally, we point out that the encounter-interviews, by composing polyphonic agreements between heterogeneous elements, highlight that in the interview procedure the way of knowing is inseparable from the experience in which the communication is constituted.

Keywords: interview, experience, madness, Robert Schumann.

\section{Entrevista como Experiencia, Locura como Método: Composición de una}

\section{Ética del Encuentro}

\section{RESUMEN}

En este artículo presentamos un procedimiento de entrevista que busca romper con una posición de exterioridad en las entrevistas de investigación psicológica. Con el objetivo de actuar en discursos que ofrecen a la locura el tratamiento de un evento individual y psicológico, y tomando la vida y el trabajo de Robert Schumann como un campo más amplio de reflexión sobre la relación entre la música y la locura, realizamos entrevistas con seis intérpretes de obra del compositor, para comprender el cruce de la experiencia de estos músicos con la producción del autor y el tema de la locura. En este procedimiento de entrevista, que llamamos encuentro-entrevista, la dimensión de la experiencia es bienvenida, mejorada y explorada, haciendo que la tragicidad intrínseca de la relación música-locura opere en el encuentro. Para sostener el poder transgresor de tal relación, creamos un camino narrativo específicamente para este artículo; estrategia que utilizamos para evitar que el objeto de investigación sea capturado en un campo de determinaciones inequívocas y representativas. Finalmente, señalamos que al componer acuerdos polifónicos entre elementos heterogéneos, los encuentros-entrevistas destacan que, en el procedimiento de entrevista, la forma de conocer es inseparable de la experiencia en la que se constituye el enunciado.

Palabras clave: entrevista, experiencia, locura, Robert Schumann.

\section{Introdução: Equalizando Problemáticas}

Propomos, no presente artigo, discutir as possibilidades do método de entrevista em psicologia, articulando o tema ao relato da construção de uma pesquisa acerca da relação entre música e loucura, pesquisa que demandou a variação do método de entrevista de maneira a manter a conexão das linguagens, dos saberes e dos afetos na experiência junto a intérpretes 
musicais. Propomos que tal percurso, profundamente singular, ilumina algumas problemáticas que estão presentes no uso do método de entrevista, problemáticas que emergem quando nos detemos na dimensão produtiva e processual dos encontros pressupostos pelo método.

Qualquer encontro carrega, naquilo que nele se produz, as forças e as intensidades que o constituíram. As perguntas que formulamos em uma entrevista engendram respostas. Não apenas as perguntas, mas o contexto, quem pergunta, o local e o cenário - "um problema tem sempre a solução que merece segundo as condições que o determinam enquanto problema" (Deleuze, 1974, p. 57). Essas respostas não esgotam o problema, pois ele permanece nas condições que o produzem. Apontamos que coletar e analisar as falas de entrevistados sem considerar essas condições, isto é, os elementos heterogêneos presentes naquilo que constitui um pensamento e, portanto, a dimensão produtiva do encontro em que a entrevista se dá, carrega o perigo de reduzir a compreensão do que é dito como algo referente ao entrevistado (Machado, 2014). Se são as relações de poder e saber nas práticas cotidianas que devem ser interrogadas quando queremos analisar um fato - por exemplo, a loucura confinada à doença mental se constitui em meio às práticas higienistas, à formação das cidades, à segregação do estranho (Foucault, 2010) -, é vital, em uma entrevista, considerar e analisar a comunicação dos entrevistados como efeitos de encontros em que se cria a experiência do dizer - o que é dito e o que é vivido se engendram nesse processo.

Nesse artigo, o problema que anima as entrevistas é a relação música e loucura pensada a partir da vida e a da obra de Robert Schumann. Ampliar o campo de reflexão sobre essa relação, de maneira a não reduzi-la a discursos que oferecem à loucura o trato de um evento individual e psicológico, implicou uma experiência sensível que produzisse alterações na forma de pensar (Machado, 2017). A experiência é sempre singular, não é como um experimento que possa ser repetido. A entrevista como experiência, tal como a propomos aqui, considera a inseparabilidade das reflexões e relatos do sujeito sobre o que já foi vivido e a dimensão processual em que o vivido e o dito emergem e se constituem (Tedesco, Sade, \& Caliman, 2014) e, portanto, privilegia a dimensão processual em que coemergem o dizer e o dito. Para que a experiência possa se dar, para que algo possa nos acontecer ou nos tocar, é necessário um gesto de interrupção, de suspensão e de abertura para o que não se pode antecipar. É preciso uma receptividade àquilo que vem de fora, àquilo que acontece e para o que vamos dando algum sentido: sentido sempre finito, contingente, pessoal e singular (Bondia, 2002). Nos encontros-entrevistas realizados, interessaram as variações do dizer presentes no ritmo, nos silêncios, nos gestos, na entonação e nos tropeços. 
Realizadas essas considerações iniciais, discutiremos, a seguir, a relação músicaloucura tecendo um texto que se apropria, intensifica e explora pontos de uma investigação que oferecem uma perspectiva privilegiada para o uso do método de entrevistas proposto. Faremos uma descrição acerca da construção da metodologia denominada encontrosentrevistas e, em seguida, apresentaremos uma produção textual intitulada percurso narrativo, na qual focaremos as experiências heterogêneas vividas nesses encontros. Por fim, evidenciaremos alguns pontos que entrelaçam a construção dos encontros-entrevistas e a possibilidade de manter o tenso hibridismo presente na relação música-loucura.

\section{Música, Arte e Loucura: Experiências Trágicas}

Chega de explicações! Essas asfixiam o sentido. O sentido é um peixe que não pode ser mantido muito tempo fora de suas águas turbulentas. (Dubuffet, 1967, p. 176)

Em 1987, o compositor suíço Heinz Holliger compõe Cânticos do Amanhecer, peça inspirada pelo seu profundo interesse pela temática da loucura em Robert Schumann, genial compositor do século XIX, que teve uma vida marcada por sofrimentos existenciais e por uma morte trágica em meio a uma internação psiquiátrica. $\mathrm{O}$ título da peça alude à peça homônima de Schumann, a obra tardia Cânticos do Amanhecer Op. 133, um curto, sofisticado e intrigante ciclo para piano que faz referência à poesia de Hölderlin, o poeta que canta a longa espera dos deuses que se ausentaram do mundo. Schumann dedica essa peça à poetisa Bettina Von Arnim, que conheceu ambos os artistas. Escrita para coral, orquestra e fita magnética, a contemporânea Cânticos do Amanhecer fusiona poemas de Hölderlin, trechos da peça de Schumann, gravações de relatórios psiquiátricos e necrológicos, além da narração de trechos de cartas de Von Arnim. Nas cartas, a poeta se refere à profunda dor que os artistas atravessaram em seus ocasos, envoltos pela aura da loucura. Unindo os dois artistas por meio da linguagem musical, da influência e de coincidências biográficas, essa obra de Holliger engendra um espaço perturbador que lança o espectador para dentro dos temas da arte, da dor e da morte, assim como suas complexas e misteriosas articulações (Van de Hoogan, 2013).

Se atacarmos uma camada interpretativa inicial, Holliger tematiza a loucura representando duas percepções antagônicas. Na primeira, a loucura é representada pelos relatórios da autópsia, que datam da ocasião da morte do compositor Robert Schumann, após longa internação em Endenich, visando a avaliar os motivos de seu sofrimento mental: 
Considero mais apropriado partir das descobertas da autópsia do corpo, que nos dão base objetiva e segura. Os principais resultados, como naturalmente era de se esperar, vieram das investigações do cérebro. Não é de todo desinteressante se adianto a observação de que os sulcos transversais do corpo do quarto ventrículo cerebral (raízes dos nervos auditivos) se encontram bem formados e em grande número. Quanto às anormalidades, apresento-as em seguida, em ordem crescente de relevância, segundo sua importância genética: 1) derrame nos vasos sanguíneos, principalmente no cérebro; 2) hiperosteose na base do crânio, com desenvolvimento especialmente irregular das enervações normais, ocasionando a formação de massas ósseas anormais, que pressionavam com seu final pontudo a meninge externa (Holliger, 2013, pp. 49).

O discurso psiquiátrico, apoiado na racionalidade anátomo-clínica, visa a fornecer um saber objetivo e seguro da loucura, que transforma a existência turbulenta de compositor em reflexos da constituição do corpo objetivado do artista. A música seria resultado da boa formação dos nervos auditivos, e a loucura, transfigurada em doença mental, teria por origem e causa os derrames sanguíneos e a hiperosteose na base do crânio - loucura objetivada, objeto natural disposto de forma transparente e passiva diante da racionalidade científica. Outra percepção da loucura de Schumann, presente na composição de Holliger, é expressa pela carta de Bettina von Arnim à esposa do compositor, Clara, após visitá-lo no asilo psiquiátrico, em 1855:

Nota-se claramente que seu espantoso mal foi apenas uma crise nervosa, que poderia ter acabado bem mais rapidamente se o tivessem compreendido melhor, ou mesmo se tivessem pressentido o que tocava seu íntimo, só que isso não ocorreu ao senhor Richarz, um hipocondríaco... ele não apenas foi incapaz de compreender a nobreza de alma do senhor Schumann, como ainda a tomou como sintoma de sua doença (Holliger, 2013, pp. 48).

Aqui, a loucura é percebida como manifestação de uma alma extraordinária e nobre que sofre duplamente: sofre da sua própria sensibilidade exacerbada e conflitiva, assim como, também, da incompreensão daqueles que não possuem a mesma alma nobre, arautos de uma sociedade mesquinha, destituída de valores poéticos e transcendentes. Quase impossível não ligar tal representação à percepção romântica do artista, fornecendo um dos elos mais duradouros, em nossa cultura, da relação arte-loucura. Ou seja, a loucura é tomada ou como 
dado natural - e, mais profundamente, como um "não ser" fundamental do indivíduo moderno -, ou então, pelo contrário, como plena realização humana, como emblema do espírito nobre que se choca com a crueldade do sombrio mundo social. Embora superficialmente antagônicas, as duas concepções da loucura apresentadas compartilham a mesma estrutura perceptiva no que tange à relação sujeito-objeto, pois oferecem a loucura como um evento individual e psicológico extraordinário (Frayze-Pereira, 1995), com o qual podemos tecer uma relação de temor ou fascínio, mas a partir de uma posição de suposta exterioridade, posição que mantém a loucura como uma questão do outro, que não fala sobre nós.

A obra de Holliger, eficaz e potente vetor de uma experiência estética, arregimenta essas percepções culturais hegemônicas da loucura sem se limitar a representá-las e reafirmálas. Ele as choca e as mistura, destila seus conteúdos pela arte dos sons e pelas palavras, criando um espaço em que podemos participar da estranha beleza melancólica da peça, da trágica amálgama entre a elevação e a queda, e adentrar em um perturbador hibridismo dos intensos afetos carregados pela música e pela frieza metálica da racionalidade médica, processos que podem resultar no silêncio do espectador (Frayze-Pereira, 2010). Difícil pensar a loucura, nessa obra, a partir de referências estáveis.

Esse gesto de Holliger ressoa com o famoso empreendimento de Michel Foucault em a História da Loucura (Foucault, 2010), obra na qual o pensador examina as diversas experiências que nossa civilização teve da loucura - cultos, pânicos, banimentos, negações, transgressões permitidas e jogos instáveis. Nesse exame, Foucault visa, a partir do trabalho do pensamento, a extrair a força contestatória da loucura, desenterrando e explorando campos de problemáticas soterrados pelo pensamento hegemônico, espaços nos quais acontecem as escolhas e lutas fundamentais da nossa cultura. Segundo Foucault, nós, ocidentais velhos de cinco séculos, nunca estamos à distância da loucura, mas sempre na distância da loucura, espaço-tempo em que se forma a maneira como o homem moderno definiu - e define - sua identidade e seu campo de possibilidades ao mesmo tempo em que a loucura é guardada como fundamental reserva de sentido, dobra vazia da linguagem, espaço habitado por uma potência de existência não aprisionada a uma determinação definida a priori (Foucault, 2014).

Seguindo a construção da história da loucura promovida por Foucault, é na Renascença, considerada o nascimento oficial da modernidade, que a loucura emerge como problemática fundamental da nossa civilização, como experiência propriamente trágica. Em sua circulação livre - tal como a "nau dos loucos", os monólogos de Hamlet e as aventuras reais-imaginárias de Dom Quixote -, a loucura é o emblema fundamental de uma experiência cósmica, composta pelo face-a-face com a morte - o vazio de uma existência cujo sentido se 
torna enigma -, pela mútua implicação entre o real e o imaginário, o humano e o inumano, a imagem e palavra, o sujeito e objeto, relações que revelam a loucura como lugar de passagem, o limiar por excelência (Foucault, 2010). A loucura é, portanto, esse movimento que corrói qualquer significação estável, enviando continuamente a existência, em um jogo fascinante e arriscado, para esse espaço de indeterminação, de conciliação impossível, que subjaz à experiência da nossa civilização, o "não lugar" que rege o coração do homem moderno e a liberdade transgressiva de sua linguagem (Foucault, 2014). Neste sentido, precisamos que a loucura pode ser formulada como uma experiência trágica, uma situação de desconsolo e liberdade em que a existência - pensamento, linguagem e ato - se engendra sem pontos fixos, sem o contorno fornecido por quadros de referências pré-ordenados.

Banida desse lugar prestigiado da cultura pela ascensão do racionalismo e da correlata normalização da vida social referenciada na moralidade e no utilitarismo burgueses, a loucura torna-se, assim, ao contrário da experiência renascentista, o não-ser do indivíduo moderno. Mas, como aponta Foucault, tal exclusão não é mais que um ocultamento, que sistematicamente desloca a loucura para o espaço ambíguo das margens da cultura (Foucault, 2016). Nessa exterioridade interior, a loucura realiza um secreto trabalho de contestação da ordem vigente, que explode no âmago da civilização ocidental, em especial nas obras artísticas. Entre Shakespeare e Artaud, entre Bosch e Goya, entre Cervantes e Sade, se Foucault não vê qualquer luminosa continuidade, no entanto pergunta se não existiria, nesses gestos artísticos, um mesmo movimento mutante do pensamento em direção ao limite.

Provocados por Foucault, nos perguntamos: qual seriam as possíveis articulações entre os fenômenos artísticos e a loucura? Seria impróprio atrelar toda a multiplicidade da produção artística, suas diversas poéticas e valores contrastantes, a uma mesma estética transgressiva, assim como seria inocente atribuir ao campo das artes, espaço complexo que engendra valores ambíguos do ponto de vista sociopolítico, um papel essencialmente contestatório. Devemos assumir, no entanto, que existe na arte uma dimensão que a atrela, de forma oblíqua, à loucura; ambas são problemáticas da cultura ocidental, ou seja, ambas designam um campo no qual nossa cultura não cessa de se medir, de avaliar seus valores e seu suposto progresso civilizatório (Frayze-Pereira, 1995). Processo indefinível, por meio do qual obsessivamente nos indagamos acerca de nós mesmos, a arte engendra, nas margens da cultura, experimentos formativos que, ao ligar supostas diferenças e desconectar supostas identidades, reviram o sensível, ampliando o campo de reflexão e interrogação (Frayze-Pereira, 2010). O louco e o poeta, no seu livre uso dos poderes analógicos e alegóricos da linguagem, na transgressão de 
uma ordem em que as palavras seriam reduzidas aos signos e ao que eles representariam, encontram-se

na orla exterior da nossa cultura e na proximidade maior de suas divisões essenciais, estão ambos nessa situação de 'limite' - postura marginal e silhueta profundamente arcaica - onde suas palavras encontram incessantemente seu poder de estranheza e o recurso de sua contestação (Foucault, 2016, pp. 68).

Por intermédio dos diálogos com e entre Holliger e Foucault, entre música e loucura, vislumbra-se uma das dimensões da peça de Holliger: ela não representa qualquer loucura, mas é ela mesma loucura, pertence às mesmas “águas turbulentas”, é processo criativo em que se produz a diferenciação de si e, portanto, a experiência de alteridade (Merleau-Ponty, 1980). A peça musical opera uma corrosão das identidades totalizantes, reenvia as percepções hegemônicas da loucura para uma região de inumanidade, insegurança, indiscernimento e liberdade, de onde elas, paradoxalmente, nascem, embora insistentemente neguem. No interior dessa dimensão estética, a loucura é liberta das imagens plenas e estáveis que a sufocam, recuperando sua potência de fazer diferir aquilo que pareceria imutável.

Curiosos e inquietos por essa discussão, buscamos desenvolver formas de nos colocar à escuta de dores sem corpo, de fantasmas do homem, do culto ao impossível que se condensa no termo loucura (Foucault, 2014). Para tanto, tivemos como desafio desenvolver entrevistas com intérpretes de Schumann, constituindo encontros em que a experiência desses músicos com a obra do autor e com o tema da loucura se fizesse presente (Oliveira, 2016). Nesse desafio, contamos com uma das dimensões mais características e enigmáticas da música, em particular da música instrumental: a partir de um trabalho lógico e extremamente organizado, a música instrumental proporciona uma experiência vertiginosa, que mergulha diretamente o ouvinte na intensa e virtualmente infinita criação de sentidos latentes, na medida em que não oferece nenhum significado inequívoco e objetivo, criando-se de maneira autônoma e autorreferente (Jankélévitch, 2015). Essa concepção acerca da música, em nossa cultura, é consolidada no interior do Romantismo, movimento plural no qual se encontra Schumann. Após ser relegada, pelo pensamento racionalista e pela estética clássica, ao estatuto de ruído sem sentido, prazer agradável e inocente, sem qualquer valor estético e civilizatório superior, a música instrumental é reabilitada pela tempestade romântica e elevada a modelo supremo de arte (Rosen, 1998). Seguindo uma ideia constante no pensamento romântico, toda arte deveria tentar se desembaraçar das limitações das significações e das representações, material sem 
mistério, e alcançar essa substância poética que, subjacente às cores e às palavras, na música instrumental se revela pura (Perrey, 2002). Dentre as várias reflexões que o romantismo realizou sobre a música instrumental, esta nos interessa: a música é uma qualidade secreta da linguagem, é afirmação radical do processo de criar sentido, com toda sua intensidade afetiva e reflexiva, mas livre da tirania da significação. Essa secreta qualidade da linguagem musical faz coincidência com o secreto trabalho de contestação da ordem vigente realizado pela loucura (Foucault, 2010, 2016). Essa negação da música em representar, sua relação implicada como dimensão irrepresentável da experiência, teceria, segundo Barthes (1991), relação com a loucura. Diferentemente do texto articulado, que sempre exige uma tela que convoca o significado, na relação com a música, o corpo passa para dentro dela como pura presença, sem a mediação de qualquer significado ou representação, sem nenhum substituto que não o significante:

Essa passagem, essa transgressão, transforma a música em loucura: não apenas a música de Schumann. Em relação ao escritor, o compositor é sempre louco - e o escritor nunca pode ser, já que ele está condenado a significar (Barthes, 1991, pp. 308)

Assim, podemos afirmar que a relação loucura-música interroga, sem cessar, acerca dos fundamentos do nosso próprio pensamento, injetando neles a tragicidade que o desconsola e o liberta. De modo a aproveitar essa afinidade entre música e loucura, reservamos um papel privilegiado à música instrumental nas entrevistas propostas com os intérpretes, compondo nosso esforço de produzir e acessar a experiência da loucura sem capturá-la em uma rede de determinações inequívocas e representacionais. Assim, retomando a epígrafe, o procedimento de entrevista a ser apresentado, no qual as dimensões de saber e o compromisso ético-político de liberar-se das sujeições das discursividades estão cuidadosamente entrelaçados, teve como objetivo uma forma de seguir os movimentos do "peixe inquieto", a loucura, em suas próprias águas turbulentas.

\section{A Construção dos Encontros-entrevistas}

Ampliar o campo da reflexão e acessar a relação loucura-música de uma forma estratégica que abrisse para o acontecimento, entendido este como um limite que não cessasse de produzir uma polifonia que contesta abordagens totalizantes, implicou preparar com rigor um espaço-tempo que estivesse aberto ao impensado, que o acolhesse e o deixasse agir. Para 
produzir e acessar uma experiência música-loucura, um catalisador potente desse amálgama refere-se a uma vida e uma obra musical que guardam em si aspectos vinculados à loucura. Ao nos debruçarmos sobre a vida-obra de Robert Schumann, encontramos um rico e ambíguo entrelaçamento entre existência e criação artística, arte e loucura.

Primeiro, a vida de Schumann foi um modelo exemplar da experiência do poeta romântico (Ostwald, 2010). Dotado de uma sensibilidade aguçada, criativa e conflitiva, sofreu das incertezas acerca de si mesmo, sua identidade e seu destino, assim como entrou em choque com os valores da sociedade de sua época. Em segundo lugar, o compositor, como já citado, passou pela sombria internação e pela trágica morte em uma instituição psiquiátrica. Desde então, esse evento fatal foi usado como texto subjacente à leitura de sua vida e de dimensões importantes de sua obra, e isto a partir de algumas categorias psiquiátricas historicamente articuladas, como a loucura circular, a psicose maníaco-depressiva e o mais recente transtorno bipolar (Braunschweig, 2013). Por fim, acerca do seu trabalho compositivo, sua música guarda importantes articulações com a loucura: entre os vários aspectos de suas composições, ressalta-se seu esforço em não optar pela realização de uma música programática ou por um projeto musical formalista (Perrey, 2002). Rompendo com as separações estanques, convidando para um jogo entre a vida e a obra, entre o real e o imaginário, entre a música e a literatura, a obra schumanniana, marcada pela indeterminação do sentido e dissolução das identidades, articula-se com a loucura (Barthes, 1979). Portanto, incorporando e sendo impulsionada pelas complexas dinâmicas socioculturais, estéticas e políticas que compõem o campo da recepção estética (Frayze-Pereira, 2010), a existência e a obra de Schumann carregam todas essas conexões com a loucura, de maneira múltipla e inextrincável: essa obra exigiu essa vida (Merleau-Ponty, 1980).

De modo a acessar essa mistura com a delicadeza e o refinamento que ela exige à sensibilidade e ao pensamento, escolhemos entrevistar seis pianistas de formação erudita que dedicam parte da sua carreira à obra de Schumann. Como intérpretes musicais, tais pianistas são trabalhadores e artistas cujo ofício é ouvir e executar a música de Schumann, e não compreender e representar sua loucura. Elegemos particularmente pianistas, profissão compartilhada pelo entrevistador, de modo a favorecer o surgimento e o adensamento de questões propriamente musicais, enriquecendo assim o campo comum de sensibilidade no encontro. Os intérpretes participaram da pesquisa a partir de diferentes caminhos: reconhecimento público, indicação de músicos e pesquisadores, conhecimento pessoal do entrevistador. Foi proposta aos intérpretes a realização da entrevista, em um ou mais encontros, na qual conversaríamos livremente acerca do tema "Robert Schumann". Propomos 
ainda, em meio à conversa, escutar a peça Carnaval Op. 9 - reconhecida como um microcosmo da obra schumanniana - e, após essa escuta conjunta, realizar a leitura de um pequeno resumo da biografia de Schumann a partir da cuidadosa pesquisa de Ostwald (2010).

Dessa forma, nos propomos a trazer para a entrevista elementos heterogêneos que compõem a problemática música-loucura - a presença do pesquisador psicólogo e do pianista intérprete, a escuta musical e o tema da internação psiquiátrica, a vida e a obra do compositor romântico, etc. -, acolher e participar dos desdobramentos do encontro dessa heterogeneidade, privilegiar e coproduzir gestos e propostas que sustentassem e amplificassem a polifonia da problemática. A promoção desses encontros e o manejo cuidadoso de sua mistura, buscando utilizar a força da heterogeneidade para romper pensamentos totalizantes, caracteriza o que aqui nomeamos encontro-entrevista.

Cada intérprete trazia consigo trajetórias e inquietações particulares, relações as mais diversas com a música e com Schumann. Cada um deles escolheu o local que preferiu para realizarmos a audição-entrevista. Às vezes, em salas aconchegantes, outras, em praças, ouvimos Schumann em aparelhos de som, notebooks, acompanhados ou não por partituras da peça. Os intérpretes decidiram um dia em que estivessem com um turno (manhã, tarde ou noite) livre para a escuta e a conversa. Tomando as entrevistas como encontros-entrevistas, alguns chegaram a durar mais de quatro horas, com tempo para tomar um café antes da audição, ouvir a música, fazer pausas para fumar um cigarro. Em alguns momentos, surgiu o interesse em escutar outras versões do Carnaval, outras peças de Schumann e outros compositores. Muitas vezes os próprios intérpretes generosamente executaram peças, apontaram características das obras, sentimentos despertados e desafios da execução. Houve também tempo-espaço para os intérpretes fazerem perguntas ao entrevistador, para revisitarem reflexões, para falarem livremente de muitos assuntos.

Tal como o ensaio de uma peça desconhecida ou a prática do improviso, cada encontro-entrevista inventou seu próprio tom, forma e conteúdo, criou suas variações, modulações temáticas, desenvolvimentos, rupturas e ritornellos. Em meio ao vagar de uma conversa musical, as variações provocaram formulações inquietantes, que permitiram desvios em relação às formas totalizantes e repetitivas de pensar a relação música-loucura. Os encontros-entrevistas foram gravados (áudio) e transcritos, subsidiando a escrita de narrativas para cada um deles. Como acordado no início, as narrativas escritas foram apresentadas e discutidas, e os comentários dos intérpretes incorporados ao texto. Os nomes dos intérpretes foram substituídos por pseudônimos. A partir do trabalho de transcrição, análise e criação textual de cada um dos encontros-entrevistas, foi construído, para este artigo, um percurso 
narrativo que, procurando romper com a exterioridade entre entrevistador, entrevistado, música e loucura, possibilitasse fazer advir, em conteúdo e forma, inquietações e variações engendradas.

\section{Percurso Narrativo: A Produção de Variações nos Encontros-entrevistas}

Logo em nosso primeiro encontro-entrevista, o tema da psicopatologia de Schumann se fez presente: “[...] o seu foco é a loucura, porque você é da psicologia, não? Do ponto de vista psicológico, o Schumann era uma pessoa com problemas. Ele era bipolar, né? Ele tinha essa condição, essa psicopatologia, o transtorno bipolar". Quando os intérpretes oferecem uma visão de Schumann, revelam perigos: a captura da loucura pelo discurso psiquiátrico e o silenciamento do compositor e de sua música pelo estigma da doença mental, na forma do transtorno bipolar - elementos que podem convergir para o estreitamento da experiência e da reflexão sobre a arte e a loucura. Importante notar enunciações tais como: "Você é psicólogo, né?", "seu interesse é a psicologia, a loucura, o transtorno", "olha, eu sei que você é psicólogo, mas não concordo com essa leitura" - frases que indicam que não são os intérpretes que reproduzem o discurso psiquiátrico, mas nosso encontro, carregado pela presença de um psicólogo, que traz consigo todas as imagens e símbolos ligados ao campo da loucura, do qual faz parte inelutavelmente o tema da doença mental. Quando o encontro toma outros rumos - durante a conversa disparada pela audição do Carnaval, Rebeca, jovem pianista em formação, surpreende-se pelo fato de o entrevistador conhecer um pouco de teoria musical e de piano -, a entrevista deixa de ser considerada como conversa sobre algo que a psicologia contornaria e passa a ser, também, sobre música. Em seguida, a pianista, com entusiasmo, pede para escutar mais uma vez o Carnaval, em especial dois fragmentos da peça que recebem o nome dos heterônimos de Schumann - "Eusebius, o Tímido" e "Florestan, o Improvisador" -, heterônimos que o compositor dizia expressarem a cisão e a dualidade da sua alma e usados para escrever músicas, cartas e trabalhos de crítica musical. Rebeca explica, por meio de várias reproduções, como a peça Eusebius é dotada de "melancolia, de vagarosidade e comedimento", atributos que caracterizam a "delicada repetição da lembrança", e a peça Florestan é dotada de mania - de um "ímpeto explosivo, de fragmentação e ansiedade, processos que compõem a pressa da paixão e o improviso do gênio virtuoso". Em sua experiência interpretando a música de Schumann, "tudo fica mais claro se você tem Florestan e Eusebius em mente". A bipolaridade torna-se uma questão de uso dos ritmos, da melodia e da harmonia, uma manipulação do tempo e da forma sonora, das 
imagens e dos afetos. Estados musicais da alma que devem ser acessados pelo intérprete, na medida em que são dinâmicas abertas a todos. Ressaltando a capacidade de Schumann de se sentir várias pessoas em uma só, Rebeca indica a bipolaridade como algo para além de uma característica aprisionada em um diagnóstico médico.

Os pianistas apontam que a música de Schumann é marcada por sua loucura, pois sua obra é subjetiva e psicológica. Após a leitura da biografia, localizam e identificam na música a presença dos pensamentos, afetos, dúvidas e amores, dilaceramentos e conflitos do compositor. Misturando a conversa biográfica com a musical, a noção de subjetividade não emerge, na experiência e fala dos pianistas, apenas no registro biográfico. Ouvindo e analisando o Carnaval, entre outras peças e canções de Schumann, Fernando, conhecedor das técnicas compositivas de Schumann, aponta que o compositor "não faz música programática, está num estágio superior", cria peças que não oferecem significados definidos, referências inequívocas, nem um estilo que guie com segurança o intérprete em sua execução. Em nossa conversa acerca de várias peças de Schumann, exploramos intensamente a percepção da música do compositor como um projeto sofisticado, formalmente e poeticamente aberto. Cada peça de Schumann exige ser olhada como única e que se invente um jeito de tocá-la: "Schumann deixa conscientemente sua obra aberta, com lacunas, sugestões, para que a gente crie a partir da música dele, crie nossa própria interpretação, é uma coisa subjetiva sempre”. Nesse ponto, subjetivo, para os pianistas, não aponta para psicologia de alguém. Subjetivo, nos encontros-entrevista, muitas vezes emergiu como signo do que é marcado pela abertura a processos de singularização.

Subjetivo, aqui, também é obra e ficção, que se opõem ao puro caos. Estela, pianista e professora de piano há anos e apaixonada pela obra do compositor, irrita-se com a leitura do resumo biográfico e afirma que compreender a música de Schumann como loucura seria uma idiotice. "A música de Schumann é extremamente organizada e sofisticada, tudo bem pensado, nada caótico". A ideia de loucura como impossibilidade e caos era questionada em sua fala. A irritação com a leitura do resumo é seguida pela procura de metáforas para o trabalho de Schumann. A pianista associa a música de Schumann à prática do diário, muito comum em seu tempo, lembrando que Schumann escreveu diários em quase todos os dias de sua vida. A prática do diário não é um registro da vida, mas uma poetização da vida, ela o explica como sendo um espaço de criação em que "o menino espinhento da escola pode se tornar um príncipe encantado, e você pode fingir que o ama, e você mal o conhece". De forma similar, Estela abre uma partitura de Schumann como se abre um diário de outrem. "Schumann queria se colocar na música, não ele mesmo, mas ele como poeta romântico", e 
por meio de sua música se tem acesso à força criativa que coloca tudo dentro da música conteúdo e forma de seus romances favoritos, cenas cotidianas, pessoas e ideias musicais. Emerge dessas ideias uma personagem, o Poeta, aquele que carrega o mundo e o recria, uma "subjetividade titânica", e é essa imagem romântica que deve guiar o intérprete. Ao piano, Estela executa a peça $O$ poeta fala, último fragmento do ciclo Cenas Infantis Op. 15. Por meio do uso da forma do epílogo, do ritmo rubato e da melodia quebrada, a pianista cria um clima onírico que invade a sala. A execução deixa vislumbrar uma "voz" que atravessa, escondida, todo o ciclo Cenas Infantis, cala e espera um momento de "falar". Pelas mãos de Estela, o fragmento musical conecta a música de Schumann à presença de uma subjetividade criadora que sempre transcende o já dito e já tocado, não se deixa capturar.

Tal experiência de criação e de loucura, presente na fala sobre a interpretação, surge com toda força na execução. Na experiência do encontro, os intérpretes trocam noções poéticas com o entrevistador, vasculham suas próprias memórias, utilizam seus próprios conceitos e valores. No começo da conversa, Helena diz que é "muito difícil falar de Schumann", compositor com quem a pianista tem uma relação duradoura e apaixonada. Ela tateia as palavras, fala da organização e estética de muitas peças, dos sentimentos múltiplos que despertam. Escuta concentrada as peças reproduzidas, levanta-se para fumar um cigarro na janela, convida-me para um café: a música produz inquietude. Fala da vida de musicista, da paixão pela arte musical, escuta as peças de novo, mais uma vez retoma que "Schumann usa fragmentos, cita peça dentro das peças, e assim faz com que a peça acabada soe como um improviso, como algo vivo e atual. Ele faz música que representa o próprio processo de compor, é fantástico". Mas algo a incomoda, o dizer não expressa suas ideias e sentimentos: “Não adianta falar, eu tenho que tocar, deixa te mostrar". Helena abre o piano, ensaia algumas notas para aquecer os dedos, escolhe sua partitura preferida de Schumann, Kreisleriana Op. 16. Respira fundo, fecha seus olhos em concentração, prepara sua corporeidade e ataca a peça. O primeiro movimento é rápido, seu ritmo é quebrado, mimetiza um pianista em pleno improviso virtuoso. Logo após essa tempestade, irrompe, em um contraste assombroso, o segundo movimento da obra, "muito íntimo e não muito depressa" (Sehr innig und nicht zu rasch), um canto lânguido, vagaroso e de ternura infinita. É como se cada dedo sentisse cada nota, e não quisesse abandoná-la. Duas vezes esse canto é interrompido por outros fragmentos, animados e contrastantes, para calmamente retornar em seguida, com pequenas e caprichosas mudanças. "É assim que eu converso com Schumann", diz a pianista, com uma face serena e um sorriso largo. Helena sabe o que toca, como um peixe que reconhece as 
águas turbulentas: "É sempre muito exaustivo tocar essa peça, são estilos muito diferentes, o coração fica balançando sem descanso. É uma loucura, exige muito da gente”.

O que se exige do intérprete de Schumann? Exige-se que este se implique em uma linguagem sem significados definidos, que sempre expressa o inefável (Jankélévitch, 2015), vazio e excesso indiscerníveis, atributos de toda linguagem instrumental, potencializados pela singular poética de Schumann. Executar não é interpretar, mas se precipitar em um espaço trágico, no qual impera a exigência de criação sem nenhuma baliza, apoio ou ancoradouro. A intérprete usa seu corpo para dar vida sonora a uma obra, uma presença irrecusável que exige implicação inelutável. Tal exigência enfraquece uma posição de exterioridade em relação à obra, à loucura e à vida. Na interpretação musical há entrega e precipitação em um espaço trágico e, portanto, a loucura é o método do intérprete.

Ao se entregar às oscilações de humor da música de Schumann - como bem nos lembra Barthes (1979, p. 15), humor é antes uma categoria estética que psicológica -, o intérprete não faz isso sem riscos. Verônica sente que não está no momento de tocar Schumann; pessoa muito passional, a pianista sente que a fragmentação, a oscilação e a complexidade das peças exigem que o intérprete "chegue ali, bem perto do abismo", até o limite da despersonalização, do mergulho na loucura. Nesse momento de mudanças em sua vida, a pianista se sente mais segura nas estruturas estáveis da música de Bach, Beethoven e Brahms. Verônica, ao fim da entrevista, escuta o Concerto para Piano em Lá menor Op. 54, e diz que a instabilidade e a paixão podem ser, no futuro, um guia para o exercício de sua autenticidade e liberdade. A liberdade seria, então, algo invocado pela instabilidade.

Os intérpretes, atravessados pela inconstância carregada pela música de Schumann, percebem a presença do compositor não a partir de uma objetivação da sua personalidade, mas no acesso a uma forma de perceber a existência e criar. Helena imagina Schumann como "um cara que acordava de manhã, ia tomar um café e, no caminho da rua, ia vendo as pessoas, as coisas, e vinham melodias sem parar em sua cabeça; é como se em tudo ele escutasse música, nas luzes do dia, nos gestos das pessoas, nas conversas, nos sentimentos e pensamentos". A música de Schumann seria a revelação de "uma música escondida no dia a dia, pois, mesmo sem som, tudo que existe tem um certo ritmo e uma certa melodia”. Em carta de 1838, para seu grande amor, Clara Wieck, Schumann escreve:

Eu sou afetado por tudo que se passa no mundo, e penso isso tudo do meu próprio jeito, política, literatura, e as pessoas; em seguida, eu desejo expressar meus sentimentos e encontrar uma saída para eles na música. É por isso que minhas 
composições são por vezes difíceis de entender, porque elas estão conectadas com interesses distantes; e elas são às vezes surpreendentes, pois tudo que acontece me impressiona e me impele a expressar em música (Schumann, 1983, pp. 260).

A escuta incessante da vida cotidiana, de um princípio musical que anima as coisas, engendra uma "necessidade desesperadora" de criar uma obra, provisória e emblema de um "universo fragmentado e inacabado, em constante distorção e mutação, que mistura tudo" - é assim que Helena descreve o âmago da música de Schumann, um intermezzo íntimo e cósmico (Barthes, 1979). Em meio à alegre e arriscada investigação e ao acesso à loucura da música, irrompe a dor. Helena, feliz até então em explorar, pelas palavras e pelas notas musicais, a singularidade da poética schumanniana, escuta com atenção o resumo biográfico, nitidamente se entristece com o desfecho trágico da vida do compositor, a morte por inanição no asilo psiquiátrico em Edenich. Longo silêncio, algumas lágrimas, e surge a ideia de que ser assediado por um mundo em convulsão, por suas intensidades, afetos e rupturas, pode ser muito para um "homem comum, como todos nós", pode levar à solidão dolorosa, à exaustão e a destruição do espírito. Na música de Schumann, Helena aponta em que lugares, e por meio de que processos, "vida e música trocam de lugares, a primeira sendo destruída, a segunda construída" (Barthes, 1979, p. 12), já que a pianista encontra na música do compositor uma fagocitação incessante da existência ordinária - com seus afetos, cenas e significados seguros - pela música. No interior dessa passagem da vida para a música, que dá origem a uma obra fascinante, a intérprete entrevê, em sombras e brechas, uma progressiva e dolorosa experiência de dissolução da individualidade, exaustiva errância no labirinto sem saída da própria interioridade. Essa é uma forma de compreender o destino trágico do compositor.

No entanto, invadidos pela ambiguidade e indeterminação presentes nos encontrosentrevistas, pudemos perceber na trágica vida de Schumann algo além de um fracasso e uma queda: entrevimos na mudez que o compositor progressivamente estabeleceu para com a dimensão mundana um gesto radical de evasão em direção a um universo puramente musical. Em 7 de fevereiro de 1854, 20 dias antes da tentativa de suicídio que o levou à internação, Robert Schumann escreve ao também compositor Robert Franz: "Querido Franz, não é maravilhoso que nós tenhamos a música, que nos permite escapar por um instante da mediocridade desse mundo?" (Ostwald, 2010, p. 269). 


\section{Nos Encontros-entrevistas, a Indeterminação como Direção Ética}

O estilo de trabalho-pensamento apresentado se constituiu durante e por meio da investigação. Mobilizados por um interesse intenso e difuso de investigar a dimensão estéticomusical da loucura dentro do campo da recepção estética, realizamos a pesquisa a partir de encontros-entrevistas com músicos, visando a construir uma experiência heterogênea que provocasse pensar a loucura na relação vida-obra em Schumann pelos intérpretes musicais. Essa revelação e objetivação carregavam o perigo de capturar e imobilizar a alteridade por um saber científico que objetiva a loucura e a nomeia de forma totalizante, como negativo da razão. Ao perceber e manejar esse risco, procuramos manter o tenso hibridismo presente na relação música-loucura, o que tornou necessário colocar, ativamente, nos encontros, alguns elementos heterogêneos sobre os quais o dizer seria produzido e abrir espaço para a imprevisível presença de outros: um piano fez a fala se tornar notas musicais e advirem outras falas; os intervalos para fumar provocaram recordações sobre o trabalho de Schumann. Tivemos atenção para com a qualidade do aparelho e as condições do ambiente acústico, para com as ambiguidades discursivas e afetivas que surgiam acerca da relação música-loucura e para com o entrelaçamento entre diferentes formas cognitivas-expressivas de comunicação emergentes, os gestos, as palavras e as notas musicais. Os pensamentos engendrados no encontro apontam que as formas de pensar e viver são lugares de passagem compostos na multiplicidade de elementos de diferentes ordens e em constante construção. Os encontrosentrevistas são considerados, portanto, exercícios de composição.

Ao falarmos da loucura com os intérpretes, constatamos que engendrávamos a figura e o discurso da doença mental devido à presença de um psicólogo no encontro. Analisar essa emergência como produção atrelada às contingências do encontro, e não como elemento exterior à cena e enraizado na opinião dos intérpretes, possibilitou a abertura e a atenção cuidadosa para os usos e variações de termos como "bipolaridade". Em primeiro momento, ele foi usado para marcar uma doença, um problema, e já com a música em cena, a bipolaridade variou e passou a nomear um sofisticado processo compositivo e expressivo de Schumann, que faz de sua obra abertura para uma dimensão anônima, tumultuosa e instável da existência. A imersão no universo musical também captura, desloca e transforma outros termos usuais na psicologia, como "subjetivo" ou "psicológico", que hegemonicamente apontam para uma dimensão individual e solitária da experiência. Articulados à experiência musical, tais termos tornam-se índices de uma linguagem inefável, obra aberta, cujo sentido é desperto por uma trama intersubjetiva de criação que hibridiza comunicação e singularização. 
Portanto, os encontros-entrevistas permitiram a construção de acordos polifônicos entre as forças heterogêneas que compõem a relação música-loucura, de forma que os discursos psicopatológicos e individualizantes, produções onipresentes na nossa cultura, não surgissem como significações inequívocas que limitam a experiência, mas como motivos que se submetem à variação e produzem novas compreensões acerca da loucura. A alteração promovida por elementos musicais presentes nas entrevistas - o corpo dos intérpretes, a música de Schumann, as partituras e o piano - não apenas diz outras coisas sobre a loucura, mas diz de outro modo, na medida em que essa investigação exigiu acessar aquilo que se dá na mistura entre o que os intérpretes falavam de Schumann e como tocavam Schumann. Na passagem arriscada do registro do logos para a escuta do melos, o saber-fazer do intérprete musical revela uma relação com a loucura que se afasta das significações psicológicas e biográficas, não apela às imagens míticas do caos e da desrazão, e, ao mesmo tempo, guarda suas principais características: produção incessante de sentido, instabilidade e abismo emblemas de uma liberdade exercitada como variação de si, de entrega à alteridade.

Entre as variações da loucura que emergiram, ressaltamos uma percepção da loucura como uma experiência propriamente estética que, se articulada com formulações sobre a poética de Schumann e a tempestade romântica (Oliveira, 2016), nos possibilita conceber a existência de uma psicopatologia fundamental de organização maníaco-depressiva, pathos que expressa a relação romântica com o vazio e o excesso e signos que se apresentam indiscerníveis, na ânsia informulável que devora o coração dos românticos, entre eles Robert Schumann. Desejo que engendra, alimenta e se expressa na produção musical desse personagem inefável (Barthes, 1979), obra que possibilita aos intérpretes ou ouvintes experienciar ativamente essa loucura. Nessa travessia e comunicação, a loucura deixa de ser fato absurdo e destino individual para se tornar um campo de experiências no qual qualquer sujeito pode se alojar, criar e se recriar.

O manejo que aqui propomos no percurso metodológico da entrevista fez com que a relação loucura-música, ao tornar-se campo de experimentação, engendrasse variações nas formas de pensar. Esse trabalho, não sem poucas apostas e improvisações, procurou não falar da loucura e da música de Schumann do ponto de vista dos intérpretes, mas com a loucura e junto à música de Schumann, na companhia dos intérpretes. A experiência trágica da loucura e a experiência estética da música se aproximaram enquanto modulações da mesma prática de liberdade (Foucault, 1994) que, ao impedirem o aprisionamento da loucura como evento individual, permitiram que a criação de sentidos e saberes se mantivesse conectada ao encontro, momento de produção discursiva composto pelas forças que o atravessavam. 
Nosso trajeto apresenta questões comuns na discussão sobre técnicas de entrevistas em psicologia. Desenvolvemos uma abertura constante aos processos heterogêneos presentes na entrevista, o que possibilitou o acesso explícito e intensificado a uma dimensão processual da experiência que é comum a toda entrevista, na qual o conhecimento produzido sempre está atrelado às suas condições de existência e experiência. Nesse sentido, apresentamos uma modulação no método de entrevistas em psicologia que possibilita que o pensamento se afaste de repetições que impedem processos de variação e diferenciação. Ao se abrir em direção à experiência, essa postura dá primado à ética em relação à técnica, pois permite que a indeterminação se mantenha como compromisso ético do encontro.

O trajeto aqui registrado, em seus diferentes níveis de problematização e criação, foi motivado por um exercício de si que busca não assimilar o que se deve conhecer, mas permitir a separação de si mesmo, ou seja, produzir um desvio daquele que conhece, libertando-nos daquilo que, em nós, pensa de forma silenciosa e repetitiva e nos impede de saber até onde poderíamos pensar, sentir e agir de modo diferente. Postura que, embasados em Foucault, nomeamos de ética da curiosidade (Foucault, 2017, p. 13-15). Quisemos explorar uma forma ativa e estratégica de produzir e cultivar uma experiência que, por não ser um mero evento ou acontecimento que se vive de forma passiva e se registra, é resultado de um engajamento que constrói, sem a garantia de balizas prévias, formas de acesso ao que nos faz variar - a alteridade -, região da existência marcada pela abertura à indeterminação.

\section{Referências}

Barthes, R. (1979). Aimer Schumann. In M. Beaufils, La musique pour piano de Schumann (pp. 9-16). Paris: Phébus.

Barthes, R. (1991). Rasch. In R. Barthes, The Responsibility of Forms (pp. 299-312). Los Angeles: University of California Press.

Bondia, J. L. (2002). Notas sobre a experiência e o saber de experiência. Revista. Brasileira de Educação, (19), 20-28. doi: 10.1590/S1413-24782002000100003

Braunschweig, M. E. Y. (2013). Biografical Listening: Intimaçy, Madness and the Music of Robert Schumann (Tese de Doutorado). University of California, California, Berkeley, USA. Recuperado de https://escholarship.org/uc/item/3x17409s

Dubuffet, J. (1967). Próspectus et tous écrits suivants. Paris: Gallimard.

Deleuze G. (1974). Lógica do sentido. São Paulo: Perspectiva. 
Foucault, M. (1994). Le sujet et le pouvoir. In M. Foucault, Dits et écrits (Vol. 4, pp.222243). Paris: Gallimard.

Foucault, M. (2010). História da Loucura. São Paulo: Perspectiva.

Foucault, M. (2014). Problematização do Sujeito: Psicologia, Psiquiatria e Psicanálise. Rio de Janeiro: Forense Universitária.

Foucault, M. (2016). As Palavras e as Coisas. São Paulo: Martins Fontes.

Foucault, M. (2017). A História da Sexualidade 2: o uso dos prazeres. São Paulo: Paz e Terra.

Frayze-Pereira, J. A. (1995). Olho d'Água. São Paulo: Fapesp/Escuta.

Frayze-Pereira, J. A. (2010). Arte, dor: Inquietudes entre estética e psicanálise (2a ed.). Cotia, SP: Ateliê.

Holliger, H. (2013). Cânticos da Manhã. Revista Osesp, (s.n.), 46-51.

Jankélévitch, V. (2015). La musique e l'ineffable. Paris: Éditions du Seuli.

Machado, A. M. (2014). Exercer a postura crítica: Desafios no estágio em Psicologia Escolar. Revista Psicologia Ciência e Profissão, 34(3), 761-773. doi: 10.1590/19823703001112013

Machado, A.M. (2017). A experiência sensível e a construção do problema em um trabalho de intervenção. In A. M. Machado, A. B. C. Lerner, \& P. F. Fonseca (Orgs.), Concepções e proposições em Psicologia e Educação (pp. 31-45). São Paulo: Blucher Open Access.

Merleau-Ponty, M. (1980). Maurice Merleau-Ponty. São Paulo: Abril Cultural.

Oliveira, R. (2016). Variações schumannianas: Música e loucura no campo da recepção estética (Dissertação de Mestrado). Instituto de Psicologia da Universidade de São Paulo, São Paulo, SP, Brasil. doi: 10.11606/D.47.2017.tde-08022017-093939

Ostwald, P. (2010). Schumann: The inner voices of a musical genius. Boston: Northeast University Press.

Perrey, B. J. (2002). Schumann's Dichterliebe and Early Romantic Poetics: Fragmentation of Desire. Cambridge, UK: Cambridge University Press.

Rosen, C. (1998). The Romantic Generation. Cambridge: Harvard University Press.

Schumann, R. (1983). On Music and Musicians. Berkeley: University of California Press.

Tedesco, S., Sade, C., \& Caliman, L.V. (2014). A entrevista na pesquisa cartográfica: A experiência do dizer. In E. Passos, V. Kastrup, \& S. Tedesco (Orgs.), Pistas do método da cartografia: A experiência da pesquisa e o plano comum (Vol. 2, pp. 92-127). Porto Alegre: Sulina.

Von de Hoogan. (2013). Revista Osesp, (s.n), 44.ia. 


\section{Endereço para correspondência}

\section{Richard de Oliveira}

Rua Mogi Mirim, 15, Bela Vista, Águas de Lindóia - SP, Brasil. CEP 13940-000

Endereço eletrônico: richard.oliveira@usp.br

\section{Adriana Marcondes Machado}

Rua Pedralva, 250, Alto de Pinheiros, São Paulo - SP, Brasil. CEP 05467-020

Endereço eletrônico: adrimarcon@uol.com.br

Recebido em: 22/10/2019

Reformulado em: 03/10/2020

Aceito em: 12/10/2020

\section{Notas}

* Graduação em Psicologia pelo Instituto de Psicologia da Universidade de São Paulo. Mestre e doutorando em Psicologia Social pelo Programa de Psicologia Social.

** Docente no curso de psicologia do Instituto de Psicologia da Universidade de São Paulo, graduação e pósgraduação. Mestre e doutora em Psicologia Social pelo IPUSP.

Financiamento: A pesquisa relatada no manuscrito foi financiada pela bolsa de mestrado do primeiro autor (FAPESP, No. Processo 2014/08518-1).

Este artigo de revista Estudos e Pesquisas em Psicologia é licenciado sob uma Licença Creative Commons Atribuição-Não Comercial 3.0 Não Adaptada. 